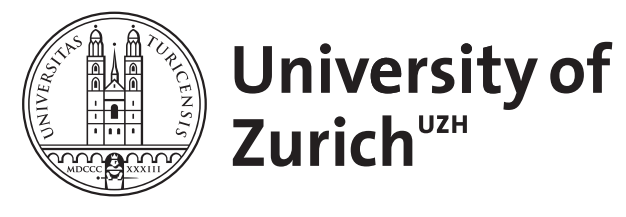

\title{
Trade policy and human rights
}

Leicht, Michael

\begin{abstract}
This year's International Labour Conference from 2nd to 18th June adopted a declaration of principles concerning fundamental workers' rights. What can the World Trade Organisation do to help establish these rights, and what economic effects can be expected?
\end{abstract}

DOI: https://doi.org/10.1007/bf02929510

Posted at the Zurich Open Repository and Archive, University of Zurich ZORA URL: https://doi.org/10.5167/uzh-156067

Journal Article

Published Version

Originally published at:

Leicht, Michael (1998). Trade policy and human rights. Intereconomics, 33(4):171-176.

DOI: https://doi.org/10.1007/bf02929510 


\title{
Michael Leicht* \\ Trade Policy and Human Rights
}

\author{
This year's International Labour Conference from 2 nd to 18th June adopted \\ a declaration of principles concerning fundamental workers' rights. What can the \\ World Trade Organisation do to help establish these rights, and what economic \\ effects can be expected?
}

$T^{\text {notate }}$ he link between trade and labour standards is probably one of the most controversial issues in the current trade debate. Although this discussion has a long history' the debate has heated up in recent years. After years of scepticism by developing countries with regard to free trade, now developed countries are afraid that free trade could destabilise their democracies. The fast integration of developing countries into the world economy after the end of the Cold War has fostered fears that the Western democracies could lose out in global competition.

Poor developing countries might not think about the long-term consequences of their actions. And authoritarian regimes and dictatorships are only interested in their own well-being, in exploiting their people and the environment. Social and ecological dumping is the consequence. Therefore the Western World has striven to address the issues of social and environmental standards in the context of the WTO. in Marrakech, by signing the WTO treaty, all the members have agreed to set up a committee on trade and the environment. But the most controversial question, the one of human rights, has been left open. At the first ministerial meeting of the WTO in Singapore, from 9th to 13th December 1996, the USA, with the support of some EU countries and Norway, wanted to set up a WTO working party to discuss the issue of social standards and its impact on world trade. But strong resistance from developing countries and from business organisations lead to the meagre conclusion in the final declaration "that the

\footnotetext{
- University of Zurich, Switzerland. The author would like to thank Ms. Liana Simopoulos, Administrator DG I, European Commission and Prof. André Sapir, President of the Institut d'études europeennes, Université Libre de Bruxelles and Economic Advisor to the European Commission for their kindness in discussing this issue with him despite diverging views.
}

WTO and ILO Secretariats will continue their existing collaboration". At the second ministerial meeting in Geneva, from 18th to 20th May 1998, no further progress on the issue could be made.

In the following we will look at the theoretical relationship between trade policy and human rights. To develop the trade agenda three essential questions must be dealt with:

$\square$ are human rights universal values or are they something exclusively European?

$\square$ are human rights and labour standards a luxury good or does respecting them help development?

$\square$ and correlated, is free trade the best way for their promotion or can sanctions help?

We will answer the last two questions first and then come back to the more fundamental question about the universality of human rights.

\section{Trade Policy and Labour Standards}

The protracted rise in unemployment in many industrialised countries and in wage inequality in some countries (especially the USA) has led some observers to look for external explanations, including claims of unfair trade practice associated with competition from firms that allegedly base their comparative advantage on low labour standards. This view is challenged by those who see technological change in connection with internal structural rigidities as the key factors for unemployment. Low social

\footnotetext{
' For an overview of labour standards in historical perspective see D K. Brown, A. V. Deardorff and R. M. Stern: Internationa Labor Standards and Trade: A Theoretical Analysis, in: J. N Bhagwati and R. E. Hude c (eds.): Fair Trade and Harmonisation Prerequisites for Free Trade? Vol. I - Economic Analysis, Cambridge and London 1996, pp. 229-236.
} 
standards and labour costs are, on the other hand, in their view the only comparative advantage developing countries have.

The debate has focused on the human rights' dimension of certain labour standards. It is argued that some labour standards reflect basic human rights and that every country in the world should therefore adhere to those standards. This position firmly rules out any discussion on salary differentials.

'Core' labour standards are defined as: freedom of association and collective bargaining, elimination of exploitative forms of child labour, prohibition of forced labour and non-discrimination in employment. These are called 'core' labour standards because their effect on economic efficiency is neutral or positive regardless of the level of development of an economy. Therefore core labour standards may be distinguished from those not in the core by the fact that the latter are a function of development while the former are not.?

From an economic point of view, it can be argued that the improved enforcement of non-discrimination standards and prohibition of forced labour might raise economic efficiency by ensuring that the allocation of labour resources moves closer to a free-market situation. The conditions of forced labour eliminate the ability of workers to make choices about where, when and under what conditions they will supply their labour. And under discrimination some individuals may not end up employed in the jobs to which they are best suited. The result of both is market distortion. ${ }^{3}$

The economic effects of freedom of association and the right to collective bargaining depend on a variety of factors. On the one hand, these rights can increase workers' motivation and productivity. On the other hand, they can introduce a new distortion into the market if unionised workers succeed in raising their wages and working conditions above market levels and keeping competitors out. The net outcome on economic efficiency depends on the relative importance of these two effects. Empirical research done by the OECD' suggests that there is no correlation between real-wage growth and the degree of observance of freedom-of-association rights. ${ }^{5}$

\footnotetext{
2 K. A. Swinnerton: An Essay on Economic Efficiency and Core Labour Standards. The World Economy, Vol. 20, No. 1, 1997, p. 74.

3 Ibid., pp. 76-78.

4 OECD: Trade, Employment and Labour Standards: A Study of Core Workers' Rights and International Trade, Paris 1996.
}

The exploitation of child labour is likely to undermine long-term economic prospects to the extent that it hampers children's education opportunities and degrades their health and welfare. But in this case development considerations must also be taken into account. Education opportunities are partly a luxury good. On the other hand, children are often sent to work out of short-term interests or cultural prejudices (e.g. women don't need education) even though schooling is available. Finally, there is no evidence to suggest that low-standard countries enjoy a better global export performance. ${ }^{6}$

The central message is therefore clear:

$\square$ those labour standards that embody basic human rights can stimulate economic development and are therefore in the interest of all workers (and countries) in the world;

$\square$ observance of these labour standards could neutralise protectionist pressures, thus securing support for free trade.

At this year's International Labour Conference from 2nd to 18th June this message was heard. Responding to the request of the WTO Singapore Ministerial Conference to act in the area of labour standards, the representatives from the ILO member states have adopted a declaration of principles concerning fundamental workers' rights together with a new ILO convention aiming at eliminating extreme forms of child labour. And they have also approved a follow-up mechanism. It is hoped that the new declaration on fundamental workers' rights can help 'core' labour standards to be respected world-wide.

The declaration builds on already internationally accepted ILO conventions. It should foster respect of the four principles of freedom of association and collective bargaining (convention nos. 87 and 98), prohibition of forced labour (convention nos. 29 and 105), elimination of child labour (convention nos. 138), and non-discrimination in employment (convention nos. 100 and 111). All seven conventions have been ratified so far in only 36 countries. But the adoption of the declaration on fundamental workers' rights by the International Labour Conference (the supreme

\footnotetext{
S But A. Banerji and H. Ghanem (Does the Type of Political Regime Matter for Trade and Labor Market Policies?, in: The World Bank Economic Review, Vol. 11, January, 1997, p.188) find that authoritarian regimes that did not respect freedom of association tended to be linked with policies restricting trade and distorting labour markets. And on the other hand, the granting of rights like freedom of association can foster the transition to democracy.

${ }^{5}$ The OECD study Trade, Employment and Labour Standards (op. cit.) gives an analytical and empirical analysis of all relevant aspects.
} 
deliberative body of the ILO) means that the ILO's 174 member states, including all the members of the WTO, recognise their duty to observe these principles whether or not they have formally adhered to the corresponding international labour conventions. Thus, the adoption of the ILO declaration represents a small breakthrough. It can be understood as "the first universal recognition that the globalised economy must rest on ground rules designed to promote social justice and human dignity".' But the problem lies in the weak enforcement mechanism. The ILO only has a monitoring system and no binding enforcement mechanism.

\section{Promotion of Human Rights}

Which strategy is best to promote human rights and democracy? ${ }^{8}$ Which is the best forum for promoting labour standards and human rights? And which are the best means? Some, like Barro, ${ }^{9}$ argue that economic development promotes democracy, while others claim this regularity is simply a chance by-product of the fact that countries with democratic political cultures industrialised first. If democracy is simply another element of social and economic development, then our policy toward countries with authoritarian regimes should embrace free trade to foster the process of economic development, thereby hastening the eventual replacement of authoritarian regimes with more democratic successors. By contrast, if democracy is not a by-product of economic and social development, promoting free trade may not be the route to free elections and respect of human rights.

Londregan and Poole ${ }^{10}$ find that higher income promotes the emergence of democratic political institutions, but the democratising effects of high income are modest. And Przeworski and Limongi"

\footnotetext{
' Michel Hansenne, directorgeneral of the ILO, quoted in the International Herald Tribune, 4/6/98

- A present-day political philosopher like Micheal Doyle argues that liberalism carries a dual legacy: peace among liberal states and interventions by liberal in nonliberal states: M. Doyle: Kant, Liberal Legacies and Foreign Affairs, in: Philosophy and Public Affairs, Vol. 12, No. 3, Summer 1983, pp. 205-235.

${ }^{2}$ R. J. Barro: Democracy and Growth, in: Journal of Economic Growth, Vol. I, March 1996, pp. 1-27.

$\circ \mathrm{J}$. B. Londregan and K. T. Poole: Does High Income Promote Democracy?, in: World Politics, Vol, 49, October 1996, pp. $1-30$
}

Christian Joerges/Karl-Heinz Ladeur/Ellen Vos (Eds.)

\section{Integrating Scientific Expertise into Regulatory Decision-Making}

National Traditions and European Innovations

Reference to scientific expertise and regulatory decision-making has become common also within the European legal system. This trend has become especially important in the context of the European policy of completing and managing the internal market.

The present volume comprises contributions by American, British, French and German lawyers and social scientists as well as officials and standardization experts from France and Brussels. It deals with general problems of integrating scientific expertise into legal framework of risk regulation. Its focus, however, are the specifics of European regulatory policies which are discussed with the examples of foodstuffs law and standardization.

The volume is addressed to academics and practitioners interested in the understanding and functioning of European regulatory policies.

Christian Joerges is a Co-director of the Centre of European Law and Politics in Bremen and part-time professor at the European University Institute, Florence; Karl-Heinz Ladeur was until 1996 professor at the EUI and now teaches law at the University of Hamburg; Ellen Vos is a Marie Curie Research Fellow at the Centre for European Law and Politics.

1997, 344 pp., paperback, 78,- DM, 569,- $0 S, 71,-s F r$, ISBN 3-7890-4855-0

(Schriftenreihe des Zentrums für Europäische Rechtspolitik an der Universität Bremen (ZERP), Vol. 23) 
come to the conclusion that democracy is not a byproduct of economic development, but can be initiated at any level of development. More wealth only increases the survival chances of a young democracy. Therefore political conditionality can foster the transition to democracy. From this perspective, the EU has done well to impose human rights clauses in all its cooperation agreements and to provide legal bases for sanctions. ${ }^{12}$ But to secure the coherence of the multilateral trading system, unilateral measures should be kept to an absolute minimum. Therefore, actions to promote 'core' labour standards, representing human rights, should take place within the framework of the WTO.

Important in this regard are the potential effects of sanctions. These are ambiguous. On the one hand they can support the ruling dictatorship, because the scarce resources the government can control are becoming more valuable. On the other hand sanctions (sometimes the threat is enough) can trigger political change. Using an interest group model we can distinguish essentially four different factors: on the material level we have to distinguish the relative effect of the embargo on the income of the different groups, and whether government supporting groups are hurt more by the sanctions than the opposition or vice versa. On the psychological level, we must distinguish between a 'rally around the flag' reaction, a 'signal of foreign support' and a 'discouraged rent-seeker effect'. 'Rallying around the flag' or 'laager mentality' means that people are standing closer together to face the common threat from outside. But the opposite can also happen: sanctions signalling foreign support can strengthen the opposition and reduce free-riding. People who have supported the government may cease to do so because they anticipate a reversal of power. ${ }^{13}$

Empirical studies analysing all major sanction cases since World War Two show that they have been

\footnotetext{
'A. Przeworski and F. Limongi: Modernization - Theories and Facts, in: World Politics, Vol. 49, January 1997, pp. 155-183.

12 D. J. Marantis: Human Rights, Democracy, and Development: The European Community Model, in: Harvard Human Rights Journal, Vol. 7, Spring 1994, pp. 1-32.

${ }_{13}$ W. H. Kaempier and A. D. Lowenberg: International Economic Sanctions - A Public Choice Perspective, Boulder 1992 pp. 115-135; and Analyzing Economic Sanctions: Towards a Public Choice Framework, in: Odell and Willett (eds.): International Trade Policies: Gains from Exchange between Economics and Political Science, Ann Arbor, 1993, pp.182-189. Kaempfer and Lowenberg base their analysis on a model developed by $G$. S Becker: A Theory of Competition Among Pressure Groups for Political Influance, in: Quarterly Journal of Economics, Vol. 98, 1983, pp. 371-400; and Public Policies, Pressure Groups and Dead Weight Costs, in: Journal of Public Economics, Vol. 28, 1985, pp. 329-347.
}

successful in one third of all cases. ${ }^{4}$ The probability of success of sanctions is the highest if the target country is small and there is political unrest, the sanction period is relatively short and the former trade linkage was high. ${ }^{15}$

We can conclude that democracy and respect of human rights are not linked to economic development. And sanctions, even though ambiguous in their effect, can help to promote the respect of human rights and labour standards. Therefore political conditionality of trade is justified. But to secure the coherence of the multilateral trading system actions should take place within the framework of the WTO.

\section{Universal Human Rights or Cultural Relativism?}

Finally, there is the philosophical discussion as to whether human rights and democracy are universal values or whether they are something exclusively European. President Jiang Zemin, for example, claimed at a US-Chinese summit that "concepts on democracy, on human rights, and on freedoms are relative". ${ }^{-6}$ Proponents of the cultural relativist point of view see cultures as closed entities, best symbolised by the image of a globe (e.g. Herder). But a more accurate description of a culture (reflecting the multifarious intracultural variances and intercultural invariances) is the concept of 'bricolage' (C.-L. Strauss). Cultures are no longer seen as completely juxtaposed to one another, completely incommensurable, but more as flowing over into one another, expressing different facets to a different degree. ${ }^{17}$ Such a metaphor is open for the various cultural invariants - like human rights.

The idea of democracy and human rights is nothing specifically European. The problem of just rule has bothered mankind since human existence. In the 'Epic of Gilgamesh', dating back to the third millennium before our time, we find the following warning to Gilgamesh, the great king of Uruk: "But do not abuse this power, deal justly with your servants in the palace, deal justly before (the god, the sun) Shamesh". ${ }^{18}$ And

\footnotetext{
$\because$ G. C. Hufbauer, J. J. Schott and A. K. Elliott: Economic Sanctions Reconsidered - History and Current Policy, Institute for International Economics, Washington D.C. 1990.

is P. v. Bergeijk: Economic Diplomacy, Trade and Commercial Policy: Positive and Negative Sanctions in a New World Order, Aldershot 1994, pp. 71-97

Cf. International Herald Tribune 31/10/97.

"E. Holenstein: Kulturphilosophische Perspektiven, Frankfurt 1998, pp. 268, 326

18 The Epic of Gilgamesh, London 1972, p. 70
} 
Confucianism is not hostile to human rights, as the present Chinese dictators would like to have us believe. On the contrary, Mengzi $(-372$ to -281$)$, the 'second genius' and successor of Confucius, developed the idea that each man has his self-dignity. Everyone has a sense of justice and the inborn capacity to distinguish between good and bad. Rulers therefore have a moral duty to respect their people. All men have a heart $x i n$, which does not allow them to accept the suffering of others. Whoever does not have a feeling of right and wrong is not a human being. The feeling of sympathy is the starting point of humanity ren. ${ }^{19}$ And in Indian culture the Mahabharata lays foundations for the respect of human rights. Rulers should protect their people with all their means. ${ }^{20}$

Very interesting is the case of the League of the Iroquois founded in the first half of the 15th century and uniting peacefully all Iroquois in a confederation. All adult men and women elected and deposed its sachem (leaders of the league), chiefs and Keepers of the Faith. "All the members of an Iroquois gens were personally free, [...] they were equal in privileges and in personal rights, the sachem and chiefs claiming no superiority." 21

These examples should be enough to show that roots for the respect of human rights can also be found in non-European cultures.

\section{Conclusions and Policy Implications}

We have seen that human rights are a truly universal concept. Non-western cultures also encourage the respect of human rights. Their promotion does not depend on the level of development. Respect of 'core' labour standards is neutral or raises economic efficiency. And political conditionality and sanctions can foster the respect of human rights and labour standards.

If core labour standards enhance economic efficiency, the obvious question is: why are they not observed world-wide? Poverty and dictatorial or authoritarian regimes make the respect of these human rights difficult. Short-term interests and rentseeking predominate. Therefore the international enforcement of core labour standards is needed and

\footnotetext{
19. H. Roetz: Die Chinesische Ethik der Acnsenzeit, Frankfurt 1992 p. 322; Konfuzius, München 1995, p. 102; and Konfuzius und die Würde des Menschen, in: Die Zeit, No. 47, 15. 11. 1996, pp. 12-13.

20 The Mahabharata, The Asanusasana Parva - The 13th Book, Section XXXII, Calcutta, pp. 167-170.
}

would in the long term be beneficial (i.e. developing countries will benefit, thanks to higher growth, and developed countries will benefit from more exports and less social dumping). Short-term losers will be consumers from developed countries, who might have to pay a slightly higher price, and especially the rent-seeking ruling class from developing countries who exploit their people. We therefore agree with Brown, Deardorff and Stern ${ }^{22}$ when they write: "... World welfare is best served by eliminating market failures where they exist, and the labour market is no exception. To the extent that labour standards are the appropriate remedy, then national governments should certainly enact them. ... But a breakdown in the political process may prevent governments from enacting legislation that corrects market failure." This is the decisive point. Because of very incomplete political markets in developing countries, characterised mostly by dictatorships, autocracies and oligarchies, the interests of the working poor are normally not taken into account.

"Countervailing may be justified if labour standards that are necessary for efficient resource allocation have not been enacted. In this case, the absence of labour standards could depress the wages of unskilled workers world-wide." ${ }^{23}$ Imperfect political markets in developing countries preventing the respecting of 'core' labour standards give rise to problems of social dumping. To prevent this, international enforcement mechanisms should be created using both positive and negative measures.

First positive measures in the form of aid programmes and technical assistance, e.g. through the ILO, should have priority. But when this fails to help and a country continually violates core labour standards (and thereby reduces world efficiency through social dumping) negative measures are also necessary. In this regard the ILO conventions and the new declaration on fundamental workers' rights are no more than a starting point. This is because the ILO has no binding enforcement mechanism, but can only make public recommendations. But the new ILO declaration on fundamental workers' rights could be used as internationally accepted criteria for whether sanctions should be enacted or not. The new declaration covers all four aspects of 'core' labour

\footnotetext{
2: L. Morgan: League of the Hoce'rosaunee or troquois, Rochester 1851; and Ancient Society, London 1877, pp. 84-86.

$\approx$ D. K. Brown, A. V. Deardorff and R. M. Stern. op. cit., pp. $270-271$

${ }^{3}$ Ibid., p. 272
} 
standards (freedom of association and collective bargaining, elimination of exploitative forms of child labour, prohibition of forced labour and nondiscrimination in employment) and was accepted by all 174 ILO member states (including all the members of the WTO) at the International Labour Conference in Geneva from 18th to 20th May 1998.

The crucial question now from the point of view of political economy is, whether interventions to counterbalance inefficiencies in the political market in developing countries might not be counterproductive?

First, declining industries in rich industrial countries could try to use the weapon of sanctions for protectionist purposes. But it should be possible to prevent this by means of a rigid procedure. An independent WTO body, in collaboration with the ILO, could survey the respecting of labour standards (comparable to the WTO Trade Policy Review Mechanism, TPRM). Alternatively the monitoring could take place under ILO guidance. The International Labour Conference has agreed on a new monitoring system for the implementation of its declaration on fundamental workers' rights. But irrespective of how monitoring of respect for 'core' labour standards is done, in the case of prolonged major violations of human rights and fruitless warnings sanctions should be used as a measure of last resort. ${ }^{26}$

Second, sanctions might not always be successful. But seeing the political process as an imperfect market ${ }^{25}$ sanctions can be the decisive moment in changing the political equilibrium and triggering political change. Hufbauer et al. ${ }^{26}$ give the empirical evidence for the effectiveness of sanctions. Nevertheless WTO/ILO surveillance should continue and in the case of the evident malfunctioning of sanctions they should be stopped.

Unfortunately, the last two WTO ministerial meetings in Singapore and Geneva were not very helpful in this regard. In Singapore it was decided that the issue of labour standards remains a matter for the ILO and the possibility for sanctions has been ruled out. But in Geneva this summer both President

"OECD: Trade and Labour Standards, OECD Working Papers, No. 7 , Vol. IV, 1996, pp. 11-12.

is For the political process as a market see G. S. Becker, op. cit. and for the long term persistance of inefficient institutions see D. C. North: Institutions, Institutional Change and Economic Performance, Cambridge 1990.

* G. C. Hufbauer et al., op. cit.
Clinton and President Santer again stressed the importance of the issue of labour standards..$^{27}$ Therefore this political momentum could be used to introduce at least an internationally observed 'sociallabel'. Labels can improve the information available to consumers and thus enable them to make better choices.

Another path which can be pursued - lacking multilateral agreements - is the political conditionality of development aid and of guarantees for multinationals. For example, the EU, by withdrawing Burma's European trade privileges, has actually for the first time given life to the social clause. Core labour standards need to be promoted in the many economic agreements negotiated and operated by the EU with third parties. ${ }^{28}$ As Human Rights Watch demands, the EU should condition guarantees and subsidies to companies in third countries on respect for, and the promotion of, human rights. Further, initiatives for more corporate social responsibility and codes of conduct for multinational enterprises should be fostered..$^{29}$

In today's globalising world economy free trade is the best policy in the long run. But there are significant short-term adjustment costs causing legitimacy problems. There is a perception that not everyone is sharing equally in the benefits of free trade. Workers in certain sectors think that their jobs are under threat from imports from countries allowing unfair working practices. Therefore in the case of market failure (e.g. labour standards), or what Sir Leon Brittan calls the 'moral implications of globalisation', ${ }^{30}$ global interventions and rules are necessary to prevent a resurgence of protectionism.

\footnotetext{
${ }^{27}$ "We must do more to make sure that this new economy lifts living standards around the world, and that spirited economic competition among nations never becomes a race to the bottom in environmental protections, consumer protections and labour standards. We should level up, not level down. Without such a strategy, we cannot build the necessary public support for the global economy. Working people will assume the risks of a free international market if they have the confidence that this system will work for them." President B. Clintion, president of the United States, at the WTO Geneva ministerial meeting, 18 May 1998

${ }^{28} \mathrm{~B}$. Jordan, general secretary, International Confederation of Free Trade Unions (ICFTU), making a statement on 'Labour rights: international instruments and their application' before the Committee on Foreign Affairs, Security and Defence Policy, Subcommittee on Human Rights in a public hearing on the social clause, 'Human Rights Promotion or Protectionism?', in Brussels, 17 and 18 June 1997.

${ }^{2}$ R. Dicker, Associate Counsel and Director, Corporations and Human Rights Programme, Human Rights Watch making a statement on 'Human Rights and the activities of Multinational Enterprises' in a public hearing on the social clause, in Brussels, 17 and 18 June 1997

${ }^{30}$ Sir L. Brittan: Globalisation: Responding to New Political and Moral Challanges, World Economic Forum, Davos, 30 January 1997.
} 